\title{
Crop Response to Different Mulch Type and Furrow Irrigation Methods in Major Irrigated Areas of Ethiopia: A Review
}

\author{
Gebeyehu Tegenu \\ Ethiopian Agricultural Research Institute Debre Zeit Agricultural Research Center \\ P.O.Box 32, Debre Zeit, Ethiopia
}

\begin{abstract}
The paper was focused on reviewing of different documents and research findings from studies conducted on interaction effect of different mulch type and furrow irrigation methods on different crop types on major irrigated area of the country. The coverage of the research findings conducted on mulch type and furrow irrigation method was between 2010 and 2021. Approaches followed on reviewing the papers on different mulch type and furrow irrigation methods were through reviewing journals from websites and research output reports. On this paper review, achievements of different mulch type for different furrow irrigation under diverse agroecologies are highlighted based on the current knowledge from available sources. Based on different findings the use of plastic mulch type was best option for both crop yield increment and soil moisture conservation .So in current research findings in order to use mulch for crop production purpose was best practice method due to year to year climate change and drought occurrences key solutions to avoid crop yield collapse and failure.
\end{abstract}

Keywords: mulch, furrow irrigation, crop

DOI: $10.7176 / \mathrm{JRDM} / 80-01$

Publication date: November $30^{\text {th }} 2021$

\section{Introduction}

Irrigation is a vitally in meeting the food and fiber needs for a rapidly expanding world population (Howell, 2001). Know a day; the agricultural sector around the world is under more pressure for limiting its water use, not only because of increasing water demand, but also because of climatic changes and more frequent droughts (Homayonfar et al., 2014). The challenge of feeding high population growth in the world in general and in developing countries in particular needs improvements in both water and moisture management in irrigated agriculture. To sustain the rapidly growing world population, there is a need to increase agricultural production (Howell, 2001).In irrigation water management and soil moisture conservation must be crucial to remove crop yield penalty and also crop water requirements. Special in arid and semi-arid area there is limiting amount of water source so in order to use that limiting amount water source soil water and soil moisture conservation is mandatory action using different mulching materials like plastic mulch, straw mulch and other local material. Effective management of available water resources (Awulachew et al., 2010) for crop production requires the producer to understand relationships between soil, water, and plants. Knowledge about available soil water and soil texture can influence the decision-making process, such as determining what crops to plant and when to irrigate.

Many studies focus on the use of mulch in agricultural systems (Allison, 1973; Gaur and Mukeherjee, 1980; Monks et al., 1997; Olasantan, 1999; Tolk et al., 1999; Adekalu et al., 2006; Sarkar and Singh, 2007; Głąb and Kulig, 2008; Ortiz- Ceballos and Fragoso, 2003; Campiglia et al., 2010; Fang et al., 2010; Kumar and Dey, 2011). Mulching is an effective cropping method that is used widely in annual and perennial crops for saving water and increasing soil temperature (Zegada-Lizarazu and Berliner, 2011), as well as improving crop performance and weed control (Campiglia et al., 2010). Mulching is an agricultural and horticultural technique in which very useful to conserve moisture, to improve the fertility and health of the soil, to reduce weed growth, to enhance the visual appeal of the area. Mulch may be permanent (e.g. plastic sheeting) or temporary (e.g. bark chips). It may be applied to bare soil, or around existing plants. In our country the use of mulch for crop production still not expanding and properly used. It may be not overblown shortage of water resource and not water costing systems.

\section{MATERIALS AND METHODS}

The material used for reviewing of such paper was different research conducted on different parts of the country and outputs on integrated effect of Mulching and Furrow Methods different crop types were reviewed.

This includes journals from online websites using www.goole.com search and other useful materials

\section{RESULTS AND DISCUSSION}

Maize

Different mulch type and furrow irrigation methods have a significant improvement on maize yield indifferent research findings. Meskelu et al. (2018) reported that the analysis of pooled mean revealed that 1000-seed 
weight was significant $(\mathrm{p}<0.05)$ influenced due to different types of furrow irrigation water management methods. On the other hand, different mulching type had no significant effect on 1000-seed weight. The highest (347.1 g) 1000-seed weight was obtained at conventional furrow method and it was statistically similar with that of alternate furrow method. On the other hand, the minimum (304.3 g) 1000-seed weight was obtained at fixed furrow a condition which was statistically inferior to both conventional and alternate furrow method. On the other hand the analysis of pooled means and both season data reveled that different types of furrow irrigation water management methods influenced aboveground biomass and grain yield of maize highly significantly $(\mathrm{p}<0.01)$. Maximum aboveground biomass $(28.28 \mathrm{t} / \mathrm{ha})$ and grain yield $(6.29 \mathrm{t} / \mathrm{ha})$ were observed at conventional furrow irrigation water application method. The maximum aboveground biomass and grain yield obtained at conventional furrow method were statistically superior to both alternate and fixed furrow methods. Contrary to this, minimum aboveground biomass $(19.29 \mathrm{t} / \mathrm{ha})$ and grain yield $(4.20 \mathrm{t} / \mathrm{ha})$ were obtained at fixed furrow irrigation method. The minimum aboveground biomass and grain yield obtained at fixed furrow were statistically similar with that of alternate furrow irrigation method. The highest aboveground biomass and grain yield of maize obtained at conventional furrow irrigation method lead to an improvement of 46.6 and $49.8 \%$ than the fixed furrow method, respectively.

The analysis of pooled means and both season data also revealed that different types of mulch on maize had a highly significant $(\mathrm{p}<0.01)$ influence on aboveground biomass. Moreover, grain yield of maize was significantly $(p<0.05)$ affected by different types of mulch. Maximum aboveground biomass $(22.59 \mathrm{t} / \mathrm{ha})$ and grain yield (4.98t/ha) were observed at plastic mulching condition. The maximum aboveground biomass obtained at plastic mulching was statistically superior to both treatments which followed by straw mulching condition. Moreover, the minimum (20.73 t/ha) aboveground biomass obtained at no mulching condition was statistically inferior to both treatments. On the other hand, the maximum grain yield obtained at plastic mulching condition was statistically similar with that of straw mulch. Moreover, the minimum (4.67 t/ha) grain yield obtained at no mulching condition was statistically similar with that of straw mulch. The highest aboveground biomass and grain yield of maize obtained at plastic mulching lead to an improvement of 19.1 and $16.9 \%$ over the conventional non-mulching condition. The research conducted on wondogent research center showed that maximum above ground biomass and 1000-seed rate both on conventional furrow irrigation method and plastic mulch. This might be due to highest and adequate soil moisture content in the root zone leads to improve aboveground biomass and grain yield of maize.

Similarly the study conducted at were Werer Agricultural Research Center area revealed that above ground biomass production of maize was maximized $((24654.30 \mathrm{~kg}$ ha-1)) with conventional furrow irrigation method and $(7930.40 \mathrm{~kg} / \mathrm{ha})$ was obtained from white plastic mulch (Abebe et al. 2020). Those finding could be important information for the production of maize both using different mulch type and furrow irrigation method.so as the result showed that as the soil moisture more conserved the crop yield also increased where similar agro-ecology and soil type .alternative furrow irrigation method with plastic mulch were best practiced and option both in grain yield production and water use efficiency.

Table: 1 . Means of yield and yield components (pooled mean).

\begin{tabular}{|c|c|c|c|c|c|c|c|c|c|c|c|}
\hline & \multicolumn{2}{|l|}{ Treatment } & $\mathrm{PH}$ & $\mathrm{CD}$ & CL & CWWS & CWWOS & AgBM & & TSW & WUE \\
\hline & $\begin{array}{l}\text { Irrigation } \\
\text { type }\end{array}$ & CFI & $155.7^{\mathrm{a}}$ & $4.67^{\mathrm{a}}$ & $17.12^{\mathrm{a}}$ & $190.2^{\mathrm{a}}$ & $48.5^{\mathrm{a}}$ & $28.28^{\mathrm{a}}$ & $6.29^{\mathrm{a}}$ & $347.1^{\mathrm{a}}$ & $1.15^{\mathrm{a}}$ \\
\hline \multirow{8}{*}{ 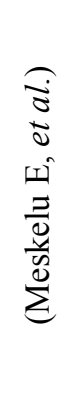 } & & AFI & $125.6^{\mathrm{b}}$ & $4.35^{\mathrm{b}}$ & $15.12^{\mathrm{b}}$ & $138.0^{\mathrm{b}}$ & $33.3^{b}$ & $20.43^{\mathrm{b}}$ & $4.64^{b}$ & $341.0^{\mathrm{b}}$ & $1.69^{\mathrm{a}}$ \\
\hline & & FFI & $121.9^{b}$ & $4.27^{b}$ & $14.71^{\mathrm{b}}$ & $126.2^{\mathrm{b}}$ & $31.0^{\mathrm{b}}$ & $19.29^{\mathrm{b}}$ & $4.20^{\mathrm{b}}$ & $304.3^{b}$ & $1.53^{\mathrm{b}}$ \\
\hline & \multicolumn{2}{|l|}{ LSD 0.05} & 6.94 & 0.09 & 0.74 & 15.55 & 4.42 & 1.68 & 0.53 & 30.2 & 0.12 \\
\hline & Mulch type & Straw & $134.9^{\mathrm{a}}$ & $4.43^{b}$ & $15.52^{\mathrm{b}}$ & $149.5^{b}$ & $36.1^{b}$ & $22.59^{\mathrm{b}}$ & $4.98^{\mathrm{ab}}$ & 332.6 & $1.40^{\mathrm{b}}$ \\
\hline & & Plastic & $140.3^{\mathrm{a}}$ & $4.53^{\mathrm{a}}$ & $16.56^{\mathrm{a}}$ & $165.10^{\mathrm{a}}$ & $41.50^{\mathrm{a}}$ & $24.68^{a}$ & $5.46^{\mathrm{a}}$ & 346.4 & $1.72^{\mathrm{a}}$ \\
\hline & & $\begin{array}{l}\text { No } \\
\text { mulch }\end{array}$ & $128.1^{\mathrm{b}}$ & $4.33^{\mathrm{c}}$ & $14.88^{\mathrm{b}}$ & $139.8^{\mathrm{b}}$ & $35.1^{\mathrm{b}}$ & $20.73^{\mathrm{a}}$ & $4.64^{b}$ & 313.4 & $1.26^{\mathrm{a}}$ \\
\hline & \multicolumn{2}{|l|}{ LSD 0.05} & 6.49 & 0.09 & 0.74 & 15.55 & 4.42 & 1.68 & 0.53 & NS & 0.12 \\
\hline & \multicolumn{2}{|l|}{ CV (\%) } & 4.8 & 2.04 & 4.7 & 10.3 & 11.8 & 7.4 & 10.5 & 9.1 & 8.10 \\
\hline
\end{tabular}

Note a,b,c Letter with similar letter in the column are not significantly different; ns not significant at $\mathrm{p}<0.05 ; \mathrm{CV}$ : Coefficient of Variation; LSD: Least Significant Difference; CFI: Conventional Furrow Irrigation; AFI: Alternate Furrow Irrigation; FFI: Fixed Furrow Irrigation

PH: Plant Height; CD: Cob Diameter; CL: Cob Length; CWWS: Cob Weight with Seed; CWWOS: Cob Weight without Seed; AgBM: Aboveground Biomass; GY: Grain Yield; TSW: Thousand Seed Weight; WUE: Water Use Efficiency. 
Table: 2. Review on Means of yield and yield components of maize as influenced by main effects of furrow irrigation techniques and mulching materials

\begin{tabular}{|c|c|c|c|c|c|c|}
\hline \multirow{11}{*}{$\begin{array}{l}\text { (Abebe et al. } \\
\text { 2020). }\end{array}$} & \multicolumn{2}{|l|}{ Treatment } & $\mathrm{PH}(\mathrm{cm})$ & $\operatorname{AgBM}(\mathrm{kg} / \mathrm{ha})$ & $\mathrm{GY}(\mathrm{kg} / \mathrm{ha})$ & WUE \\
\hline & Irrigation type & CFI & $230.70^{a}$ & $24654.30^{\mathrm{a}}$ & $8193.00^{\mathrm{a}}$ & $1.06^{\mathrm{b}}$ \\
\hline & & AFI & $221.90^{b}$ & $21970.10^{\mathrm{b}}$ & $7333.00^{b}$ & $1.90^{\mathrm{a}}$ \\
\hline & & FFI & $218.49^{b}$ & $21675.10^{\mathrm{b}}$ & $6859.00^{b}$ & $1.78^{\mathrm{a}}$ \\
\hline & LSD 0.05 & & 6.43 & 1937.20 & 531.80 & 0.16 \\
\hline & $\mathrm{CV}(\%)$ & & 2.20 & 6.50 & 5.45 & 6.33 \\
\hline & Mulch Type & Straw & $226.30^{\mathrm{a}}$ & $22907.10^{\mathrm{ab}}$ & $7403.40^{\mathrm{b}}$ & $1.58^{\mathrm{b}}$ \\
\hline & & Plastic & $228.59^{a}$ & $23851.30^{\mathrm{a}}$ & $7930.40^{a}$ & $1.69^{\mathrm{a}}$ \\
\hline & & No mulch & $216.20^{\mathrm{b}}$ & $21541.10^{\mathrm{b}}$ & $7051.70^{b}$ & $1.49^{\mathrm{c}}$ \\
\hline & LSD 0.05 & & 7.01 & 1415.80 & 458.10 & 0.09 \\
\hline & $\mathrm{CV}(\%)$ & & 3.05 & 6.05 & 5.98 & 6.33 \\
\hline & & & NS & NS & NS & NS \\
\hline
\end{tabular}

\section{Potato}

In addition to maize, Potato (Solanum tuberosum $L$ ) production under different mulch type and furrow irrigation technique condition at Kulumsa was reported by Lindi et.al, (2018). As Lindi et,al (2018) reported that interaction effect of different mulch type and irrigation method had not significantly affected plant height at $p>0.05$. The result observed that plant height ranges from 76.7 to $80.9 \mathrm{~cm}$ under different furrow irrigation water application techniques and form 77.3 to $81.7 \mathrm{~cm}$ under different mulch type. The result of potato yield showed that, different types of irrigation method highly significantly $(\mathrm{p}<0.01)$ affected potato tuber yield. Moreover, potato tuber yield highly significantly $(\mathrm{p}<0.01)$ influenced due to different mulch types used. The interaction effect of the two factors, furrow irrigation methods and mulch types, had a significant $(p<0.05)$ effect on tuber yield of potato. The highest tuber yield of $44,866 \mathrm{~kg} /$ ha was obtained at conventional furrow irrigation method. On the other hand, the minimum tuber yield of $39,782 \mathrm{~kg} / \mathrm{ha}$ was obtained at fixed furrow irrigation method which is statistically similar with the tuber yield obtained at alternate furrow method. The maximum tuber yield of $44,136 \mathrm{~kg} / \mathrm{ha}$ was obtained under different straw mulch application. The minimum tuber yield of $39,218 \mathrm{~kg} / \mathrm{ha}$ was obtained at plastic mulch condition which was statistically similar with no mulch condition. The interaction effect showed that higher tuber yield of $50,452 \mathrm{~kg} / \mathrm{ha}$ was obtained at conventional furrow irrigation water application technique under straw mulching. Under deficit treatments, the higher tuber yield of 41,942 kg/ha was obtained at alternate furrow irrigation under straw mulch.

Table 3 Review on effect of Integrated Mulching and Furrow Irrigation Methods on Potato Yield

\begin{tabular}{|l|l|l|l|l|l|}
\hline \multirow{5}{*}{ Lindi et al(2018) } & Treatments & $\mathrm{TY}(\mathrm{kg} / \mathrm{ha})$ & $\mathrm{ABY}(\mathrm{kg} / \mathrm{ha})$ & $\mathrm{PH}(\mathrm{cm})$ & $\mathrm{WP}(\mathrm{kg} / \mathrm{ha})$ \\
\cline { 2 - 6 } & AFI( Alternative Furrow & $40352 \mathrm{~b}$ & 11600 & 75.98 & $19.02 \mathrm{a}$ \\
\cline { 2 - 6 } & FFI (Fixed Furrow Irrigation) & $39782 \mathrm{~b}$ & 12637 & 78.64 & $18.75 \mathrm{a}$ \\
\cline { 2 - 6 } & CFI (Conventional Furrow Irrigation) & $44866 \mathrm{a}$ & 12908 & 78.71 & $10.57 \mathrm{~b}$ \\
\cline { 2 - 6 } & SM(straw mulch) & $44136 \mathrm{a}$ & $13685 \mathrm{a}$ & 76.11 & $16.84 \mathrm{a}$ \\
\cline { 2 - 6 } & PM( plastic mulch) & $39218 \mathrm{~d}$ & $11457 \mathrm{~d}$ & 79.89 & $15.22 \mathrm{~d}$ \\
\cline { 2 - 6 } & NM (mulch) & $41646 \mathrm{ab}$ & $12003 \mathrm{~b}$ & 77.33 & $16.28 \mathrm{a}$ \\
\hline & CV (\%) & 5.53 & 12.37 & 9.06 & 6.07 \\
\hline & LSD (0.05) & 2506 & 1665 & $\mathrm{Ns}$ & 0.97 \\
\cline { 2 - 6 } & REP & $2965.41^{*}$ & $74.60 \mathrm{~ns}$ & 175.37 & $5.95^{*}$ \\
\cline { 2 - 6 } & IM MS & $6984.41^{* *}$ & $428.92 \mathrm{~ns}$ & $21.88 \mathrm{~ns}$ & $207.25^{* *}$ \\
\cline { 2 - 6 } & MT MS & $5441.32^{* *}$ & $1213.18^{*}$ & $33.44 \mathrm{~ns}$ & $6.04^{*}$ \\
\cline { 2 - 5 } & IM MT x MS & $2000.75^{*}$ & $115.72 \mathrm{~ns}$ & $7.74 \mathrm{~ns}$ & $1.95 \mathrm{~ns}$ \\
\hline
\end{tabular}

Note: $\mathrm{TY}=$ Tuber yield, $\mathrm{ABY}=$ Aboveground Biological Yield, $\mathrm{PH}=$ Plant Hieght, $\mathrm{WP}=$ Water Productivity, $\mathrm{CV}=$ Coefficient of Variation, LSD= Least Significant Difference, REP= Replication, IM= Irrigation

Method, MS= Mean Square and MT= Mulch Type

\section{Onion}

Research conducted on onion crop in Debre zeit Agricultural research center (Ashebir et al 2021) reported that results on different types of furrow method had a significant difference $(p<0.01)$ on onion yield. The maximum Onion yield (39.5 t/ha) were observed at conventional furrow irrigation water application method. The maximum marketable Onion yield obtained at conventional furrow irrigation was statistically superior to both alternate and fixed furrow irrigation. However, minimum marketable yield (28.9 t/ha) were obtained at fixed furrow irrigation method. Therefore, the highest marketable yield of onion obtained at conventional furrow irrigation method lead to an improvement of $27 \%$ while alternative furrow was $16 \%$ than the fixed furrow irrigation method. 
In addition to different furrow irrigation method the different types of mulch on onion yield had highly significant $(\mathrm{p}<0.01)$. Therefore, maximum marketable yield of onion bulb $(37.1 \mathrm{t} / \mathrm{ha})$ were observed at straw mulching condition but the maximum bulb yield obtained at straw mulching condition was statistically similar with that of plastic mulch. Moreover, the minimum $(29.5 \mathrm{t} / \mathrm{ha})$ marketable yield obtained at no mulching condition was statistically significant different with both straw and plastic mulching. So, the highest marketable yield of onion bulb obtained at straw followed by plastic mulching showed an improvement of $20 \%$ and $18 \%$ respectively over the conventional non-mulching condition.

On the other hand, (Temesgen, T. (2018) who reported that the highest marketable yield were obtained through black plastic mulch followed by straw mulch in Onion crop. Interaction effect of deficit irrigation levels by mulching exhibited a highly significant $(\mathrm{P}<0.01)$ influence on the marketable yield. The highest marketable yield (47.25 ton ha-1) was obtained from combined application of treatment received 100\% ETc and plastic mulch whereas the lowest marketable yield (15 tonha-1) was obtained from treatment received 50\% ETc and no mulch. Based on different research conducted finding results reported that different results and conclusions. Like Lindi et al, (2018) on Potato and Ashebir et al (2021) on onion those reported that yield of potato and onion result showed minimum on plastic mulch.

Table 3.Reviewed Paper on Interaction effect of deficit irrigation levels and mulching techniques on marketable bulb yield and water use efficiency $(\mathrm{kg} / \mathrm{m} 3)$ of Onion

\begin{tabular}{|l|l|l|l|l|l|l|l|l|l|l|l|}
\hline Treatment & \multicolumn{9}{|c|}{ Marketable bulb yield (ton/ha) } \\
\hline \multirow{2}{*}{ Mulch } & \multicolumn{9}{|c|}{ WUE (kg/m3) of Onion } \\
\cline { 2 - 13 } & $100 \% E T c$ & $80 \% E T c$ & $70 \% E T c$ & $60 \% E T c$ & $50 \% E T c$ & $100 \% E T c$ & $80 \% E T c$ & $70 \% E T c$ & $60 \% E T c$ & $50 \% E T c$ \\
\hline PM & $40.8^{\mathrm{a}}$ & $33.2^{\mathrm{d}}$ & $30.9^{\mathrm{e}}$ & $25.4^{\mathrm{h}}$ & $20.8^{\mathrm{k}}$ & $7.93^{\mathrm{c}}$ & $8.05^{\mathrm{bc}}$ & $8.48^{\mathrm{a}}$ & $7.15^{\mathrm{f}}$ & $6.95^{\mathrm{g}}$ \\
\hline SM & $37.2^{\mathrm{b}}$ & $31.4^{\mathrm{a}}$ & $30.0^{\mathrm{f}}$ & $20.6^{\mathrm{i}}$ & $16.4^{\mathrm{l}}$ & $7.24^{\mathrm{ef}}$ & $7.62^{\mathrm{d}}$ & $8.19^{\mathrm{b}}$ & $6.72^{\mathrm{h}}$ & $6.34^{\mathrm{f}}$ \\
\hline NM & $35.7^{\mathrm{c}}$ & $29.9^{\mathrm{f}}$ & $28.4^{\mathrm{g}}$ & $20.0^{\mathrm{j}}$ & $15.0^{\mathrm{m}}$ & $6.95^{\mathrm{g}}$ & $7.36^{\mathrm{f}}$ & $7.36^{\mathrm{e}}$ & $6.49^{\mathrm{f}}$ & $6.11^{\mathrm{j}}$ \\
\hline Mean & 37.9 & 31.5 & 29.8 & 22.0 & 17.3 & 7.37 & 7.64 & 8.01 & 6.79 & 6.47 \\
\hline
\end{tabular}

Table 4. Reviewed Paper on combined analysis of MBY in (t/ha) and WUE (kg/m3) of Onion.

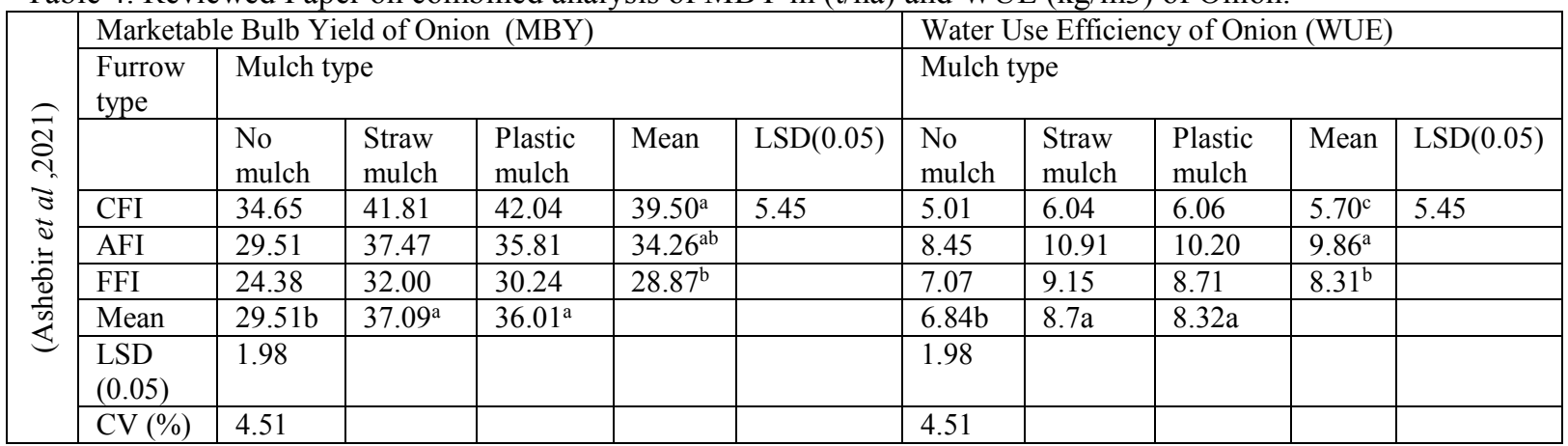

N.B. Treatments with similar letter in the column \& also in rows are not significantly different; CV: coefficient of variation; LSD: least significant difference; CFI: conventional furrow irrigation; AFI: alternate furrow irrigation; FFI: fixed furrow irrigation; WUE Water use Efficiency MBY; Marketable Bulb Yield.

\section{Conclusions}

Different Research findings on different mulch type and furrow irrigation method on different crop type at different parts of the country recommendation should be used for different irrigation conditions like fixed furrow irrigation method, alternative furrow irrigation method and different mulch type like plastic mulch, straw mulch and no mulch conditions. Research findings revealed that different mulch type under different irrigation condition significantly produced higher yield of diverse crops. Various crops under different agro-ecology and soil type were significantly different in response to mulch type. So, application of higher thickness and more soil moisture conserving mulch material like plastic mulch could be best for more yield production. Some of are recommended straw mulch are higher than the plastic mulch.

Based on different findings most of research conducted on mulch type and furrow irrigation methods are not considered cost benefit and economic analysis of mulch type and the water conserved by using mulch. In addition to this like Wed management system special in plastic mulch the wed controlling system is very difficult when the plastic covered fully the plot area. Disease controlling system on straw mulch, mulch material standards different research finding are not mention the mulch type and rate. So when researches are conducted on mulch type should be mention mulch type special straw mulch type and in plastic mulch the thickness and also color type white or black. Although different research conducted in different parts of the country especially 
in research centers when proposed research activities on mulch the mulching system should be mention like all of the plot covered or only root zone of the crop and mulch materials only one crop type or local easily available any mulch materials. Moreover, more study on effect of different mulch type option and furrow irrigation method should be studied. The findings clearly indicated the interactive effect of the moisture content conservation and furrow irrigation method has significant yield advantage over almost all the control treatment on different crop types. Generally this review aims to contribute towards the research conducted in our country based on mulch type and integrated with furrow irrigation method could be documented and also filling this gap as listed above by focusing on the use of mulch in irrigated area as a best water-saving practice.

\section{Reference}

Adekalu ko, okunade da and osunbitan ja (2006). compaction and mulching effects on soil loss and runoff from two southwestern nigeria agricultural soils. Geoderma $137 \quad(1 \quad \& \quad 2)$ 226-230. Https://doi.org/10.1016/j.geoderma.2006.08.012

Allison fe (1973) .chapter 25 use of mulches. In: soil organic matter and its role in crop production: developments in soil science. Amsterdam, the netherlands. Isbn: 0-444-4 1017-1.

Asehbir haile, solomon gezie and gebeyehu tegenu (2021). Effect of furrow method and mulch on bulb yield and water productivity of irrigated onion under central highland vertisol of ethiopia ethiop. J. Agric. Sci. 31(1) $145-157$ (2021)

Campiglia e, mancinelle r, radicetti e and caporali f (2010). Effect of cover crops and mulches on weed control and nitrogen fertilization in tomato (lycopersicon esculentum mill.). Crop protect. 29 (4) 354-363. Https://doi.org/10.1016/j. Cropro.2009.12.001 Doi.org/10.1016/s0167-1987(98)00192-5 Effect of furrow method and mulch on bulb yield and water productivity of irrigated onion [156]

Elias meskelu, henok tesfaye, ayele debebe and mulugeta mohammed (2018). Integrated effect of mulching and furrow methods on maize yield and water productivity at koka, ethiopia. Irrigat drainage sys eng 7: 207. Doi: $10.4172 / 2168-9768.1000207$

Fang s, xie b, liu d, and liu j (2010). Effects of mulching materials on nitrogen mineralization, nitrogen availability and polar growth on degraded agricultural soils. Int. J. Biol. Biotechnol. Manage. Afforestation reforestation 41 (2) 147-162.

Gaur ac and mukeherjee d (1980). Recycling of organic matter through mulch in relation to chemical and microbiological properties of soil and crop yields. Plant soil 56 273-281. Https://doi. Org/10.1007/bf02205856

Głąb $t$ and kulig b (2008) effect of mulch and tillage system on soil Porosity under wheat (triticum aestivum). Soil tillage res. 99 169-178 Https://doi.org/10.1016/j.still.2008.02.004

Homayonfar m, lai sh, zomorodian m, sepaskhah ar, a ganji, (2014). Optimal crop water allocation in case of drought occurrence, imposing deficit irrigation with proportional cutback constraint. Water resources management, 28(10): 3207-3225.

Kumar s and dey p (2011). Effects of different mulches and irrigation methods on root growth, uptake, water-use efficiency and yield of strawberry. Sci. Hort. 127 318-324. Https://doi.org/10.1016/j. Scienta.2010.10.023 March 14-16; addis ababa, ethiopia: international water management institute (iwmi).

Monks cd, monks dw, basden t, selders a, poland s and rayburn e (1997). Soil temperature, soil moisture, weed control and tomato (lycopersicon esculentum) response to mulching. Weed technol. 11 561-566. Https://doi.org/10.1017/s0890037x00045425

Nigusie abebe , yibekal alemayehu and fentaw abegaz , (2020). Effect of mulching materials and furrow irrigation techniques on yield, water productivity and economic return of maize (zea mays 1.) At werer, middle awash valley, ethiopia. Int j agri biosci, 9(4): 156-162. Www.ijagbio.com (C2020 ijab. All rights reserved)

Olasantan fo (1999). Effect of time of mulching on soil temperature and moisture regime and emergence, growth and yield of white yam in western nigeria. Soil tillage 50 215-221. Https://

Ortiz-ceballos ai and fragoso c (2003) earthworm population under tropical maize cultivation: the effect of mulching with velvetbean. Biol. Fertil. Soils 39 (6) 438-445.

Samuel lindi, mihiret hone, elias meskelu, iticha, b., webngeda admasu ,kassu tadesse, (2018). Integrated effect of different mulching and furrow irrigation techniques on potato (solanum tuberosum 1) yield and water productivity at kulumsa, ethiopia. Acad. Res. J. Agri. Sci. Res. 6(8): 488-494

Sarkar s and singh sr (2007). Interactive effect of tillage depth and mulch on soil temperature, productivity and water use pattern of rainfed barley. Soil tillage res. 92 79-86. Https://doi.org/10.1016/j. Still.2006.01.014

Seleshi bekele awulachew, merrey d, van koopen b, and kamara a. (2010). Roles, constraints and opportunities of small-scale irrigation and water harvesting in ethiopian agricultural development: assessment of existing situation. Ilri workshop; 2010

Tasisa temesgen (2018). Irrigation level management and mulching on onion (allium cepa 1.) Yield and wue in 
western ethiopia. The journal of the science of food and agriculture, 2(3), 45-56. Http://dx.doi.org/10.26855/jsfa.2018.03.001

Terry a.howell. (2001).Enhancing water use efficiency in irrigated agriculture. Agronomy journal · march 2001 doi: 10.2134/agronj2001.932281x · source: oai

Tolk ja, howell ta and evett sr (1999).Effect of mulch, irrigation, and soil type on water use and yield of maize. Soil tillage res. 50 137-147. Https://doi.org/10.1016/s0167-1987(99)00011-2

Zegada-lizarazu w and berliner pr (2011). The effects of the degree of soil cover with an impervious sheet on the establishment of tree seedlings in an arid environment. New for. 42 2-17. Https:// doi.org/10.1007/s11056010-9233-9 